\title{
STEVE JOBS - INNOVATION MANTRA - FIRST INNINGS
}

\author{
Dr. Amarja Satish Nargunde \\ Associate Professor, Department of Management Studies \\ Bharati Vidyapeeth Deemed University \\ Institute of Management and Rural Development Administration, Sangli, India.
}

\begin{abstract}
Apple was started in the bedroom of Steve' house and ended as being the most valuable company in the world. Innovation is the first reason for Apple's phenomenal success. Apple thought differently than others. Steve made Apple "Think Different." He questioned every set practice which was there in the business and found that most of the things were done because that everybody thought it was the only way to do it and didn't care to find out why it was done. During his college days, Steve got attracted towards Eastern spirituality. He became follower of Zen Buddhism. He became intense follower of it and it became a deep part of his personality. His whole approach to start, minimalist, aesthetics, intense focus can be credited to it. Buddhism's emphasis on intuition had a deep influence on Steve.
\end{abstract}

Keywords: Think Different, Innovation, success.

Cite this Article: Dr. Amarja Satish Nargunde, Steve Jobs - Innovation Mantra - First Innings, Journal of Management (JOM), 6 (6), 2019, pp. 47-55. http://www.iaeme.com/JOM/issues.asp?JType=JOM\&VType $=6 \&$ IType $=6$

\section{INTRODUCTION}

There are some of the abilities that are God gifted. An interesting explanation of why some people are gifted with extraordinary abilities can be found in an Indian author's book. The lines read, "God gives talent so that the ordinary person can become extraordinary. Talent is the only way the poor can become rich. Otherwise, in this world the rich would remain rich and the poor would remain poor. This unfair talent actually creates a balance, helps to make the world fair."

The rich and poor part can be ignored for a while. But certainly, the gifted talent separates extra ordinaries from the ordinaries. Steve's real talent was he could see things differently. So was the company he formed. One of Steve's famous quotes are, "Innovation distinguishes between a leader and a follower." Steve had his own opinions for things and refused to accept others' views without scrutiny. His spiritual upbringing too, made him have different insights of the world. 


\section{CHILDHOOD AND TEENAGE DAYS}

Steve's father had taken Steve to the family's dairy farm. One of the image of rural life made quite impression on him. He saw a calf taking birth and he was stunned when he saw this little animal started to walk after struggling for some minutes. It was normal event of life but Steve thought about it differently. He recalled, "It was not something she learned, but it was instead hardwired into her. A human body couldn't do that. I found it remarkable, even though no one else did." He could relate to hardware-software. "It was as if something in the animal's body and in its brain had been engineered to work together instantly rather than being learned."

Steve always considered himself as an artist. Musician Bono said, "The people who invented the twenty-first century were pot-smoking, sandal wearing hippies from the West Coast like Steve, because they saw differently. The sixties produced an anarchic mindset that is great for imaging a world not yet in existence." Stewart Brand who published the "Whole Earth Catalog' said, "Steve is right at the nexus of the counterculture and technology. He got the notion of tools for human use."

In 1971 when Steve was in high school, he met another Steve; Steve Wozniak who was 5 years elder to him. Both went on to make 'Blue Box' which became their first business together. Both loved playing pranks and they built Blue Box that allowed users to get free phone service illegally. The two learned about blue boxes from famed "phreaker" (phone freak/hacker) John Draper known as Captain Crunch. The nickname suggested to a whistle given away in the 1960s in Captain Crunch cereal which produced the perfect tone, $2600 \mathrm{~Hz}$, to allow a person to enter operator mode on AT\&T's phone system. The Blue Box was the first digital version which was designed to emulate the in-band signaling tones used by the telephone exchanges. Playing these tones through a speaker connected to the telephone handset's microphone fooled the automatic exchanges into thinking that they were receiving legitimate signaling information.

The box was designed by Wozniak, but it was Steve who thought that the box could be more than fun or hobby and they could be sold. The pattern of their partnership remained same after; Wozniak designed things and Steve looked after the selling part. The cost of its parts was about $\$ 40$ and Steve decided to sell at \$150.Like the Apple devices which were made later the Blue Box too didn't have any on/off switch but it automatically came to life whenever one of the keys was pressed. They stopped making the boxes after they were nearly caught by the police.

But both became interested with the idea of trying to make one of these boxes. In an interview given in 1995 Steve reflected, "We were so fascinated by them (blue boxes) that Woz and I figured out how to build one. We built the best one in the world; the first digital blue box in the world. We would give them to our friends and use them ourselves. And you know, you rapidly run out of people you want to call. But it was the magic that two teenagers could build this box for $\$ 100$ worth of parts and control 100's of billions of dollars of infrastructure in the entire telephone network in the whole world. Experiences like that taught us the power of ideas. The power of understanding that if you could build this box, you could control 100's of billions of dollars around the world, that's a powerful thing. If we wouldn't have made blue boxes, there would have been no Apple."

\section{EARLY APPLE DAYS}

Apple's first success came through Apple II, with trademark Apple. It became one of the most popular microcomputers ever. Even Altair 8800 was the first personal computer, Time magazine has given credit to Apple II for the start of the personal computer revolution. It was designed by Wozniak. It was a vast improvement over the Apple I, Apple's first computer. However, it contained the same processor and ran at the same speed as that of Apple I. 
Some of the features that microcomputers saw for the first time included a color display, eight internal expansion slots, and a case with a keyboard. It was Steve who worked for having a perfect plastic case for the keyboard. The Apple I and many other early computers didn't have a case or even a keyboard. On some systems the user had to add his own keyboard, if possible, and on others users toggled switches to enter programs and issue commands.

It was one of the first computer which had a color display, and it had the BASIC programming language built-in, so it is ready-to-run right out of the box. The earlier computers made users first load the operating system each time he or she turned on the computer. Apple II loaded the operating system automatically, which made the startup easier, even for a nontechnical user. The Apple II was probably the first user-friendly system. The most important feature of the Apple II was probably its eight expansion slots. No other computer had this kind of flexibility or expansion possibilities. The top of the computer wasn't even attached, one could lift it off easily to access system motherboard and expansion slots. Apple and other manufacturers made different expansion cards to add to the Apple II's capabilities. That included - memory expansion, floppy disk controllers, PASCAL and CP/M emulator cards, parallel, serial, and SCSI cards, processor accelerators, video cards.

It had also an innovative power supply cable. Steve hired Red Holt who built a power cable like those used in oscilloscopes, rather than that of a conventional linear power cable. It could switch on and off power thousand times, which made store the power for less time, and less heat was thrown off. Steve recalled, "The switching power supply was as revolutionary as the Apple II logic board was."

\section{MACINTOSH}

Apple II was considered Wozniak's computer. Macintosh turned out to be Steve' computer. He was intensely involved in each and every aspect of the computer. Since he took over the project from Jef Raskin Steve is called as 'adoptive father' of the Mac. Steve never believed in market research. He relied more on his intuition. Mike Murray, Marketing Chief said, "Steve did his market research by looking in to the mirror every morning."

On a couple of visits to Xerox PARC, Steve and few other Apple employees got to see Xerox's Star computer with icons, windows, folders, a mouse, pop-up menus, WYSIWYG (What You See Is What You Get) text editor, Ethernet-based local networking, and networkbased printing and games. Steve also got to see the concept of "cut, copy and paste". However, it was clunky, took minutes to save a large file and it cost $\$ 16,595$. It was made for the networked office market. But it failed in the market. Steve and his team had even gone to buy it at a Xerox retailer when it was released. But he dropped the idea of buying because he thought it was worthless.

Although Apple is often accused of copying innovative features of Xerox's computer, Apple made significant improvement in features with the Macintosh. Merely getting an idea is never enough. Executing the idea makes difference between success and failure. Steve and his team made significant improvement in the graphical interface over what they had seen at PARC. They did it in a way that Xerox could have never achieved.

One of the improvements that was made in Mac was with mouse. The Xerox mouse was looked complicated with three buttons on it. It cost $\$ 300$ per piece. It couldn't roll around smoothly. Steve approached a local industrial design firm, IDEO, and Dean Hovey, one of its founders to make a model with a single button which would cost $\$ 15$. Hovey recalled, "I had a series of ideas that I wanted to bounce off him, and I barely got two words out of my mouth when he said, 'No, no, no, you've got to do a mouse.' I was, like, 'What's a mouse?' I didn't have a clue." Steve told Hovey, "You know, [the Xerox mouse] is a mouse that cost three hundred dollars to build and it breaks within two weeks. Here's your design spec: Our mouse 
needs to be manufacturable for less than fifteen bucks. It needs to not fail for a couple of years, and I want to be able to use it on Formica and my blue jeans." Hovey got the idea of rolling ball for the mouse from deodorants.

The mouse of Xerox couldn't drag windows around the screen. For the Mac mouse engineers developed an interface which enabled the user to drag windows and files around. Plus, these files and folders could also be dropped into the folders.

Xerox computer required user to select a command for doing anything, like resizing a window. Macintosh made desktop metaphor a virtual reality where the user could directly touch, manipulate, drag and relocate things. Steve motivated the designers and the engineers for bringing improvement in the desktop. They came up with beautiful icons, menus that could pull down from a bar on the top of each window and a double click that could open files and folders.

Another significant component of the original Macintosh technology was QuickDraw. The graphics package was written by Bill Atkinson which pushed pixels around the frame buffer at blinding speeds to create the celebrated user interface. The key data structure in QuickDraw was called a "region" which required complex coding that created illusion of overlapping windows. Atkinson was under the impression that he had seen such capability at Xerox PARC. However, PARC scientists had not achieved it and they were amazed that Atkinson could make it.

During the making of the Mac, Steve took his team to an exhibit of Tiffany glass at a museum. He admired Louis Tiffany for creating great art that could be mass-produced. $\mathrm{He}$ thought there was lot to learn from. One of the design team members Bud Tribble recalled, "We said ourselves, 'Hey, if we're going to make things in our lives, we might as well make them beautiful." Steve wanted to name the computer as "Bicycle", because just the way bicycle improved human speed and efficiency, he thought computer as 'bicycle for mind'. Mac team members made him change his decision.

One characteristic that makes all Apple products stand apart from the rest is its design simplicity. Steve loved Bauhaus style of designing. In1983 at a design conference he publicly praised Bauhaus style. He believed that design simplicity meant making products easy to use. Sometimes the excellent design and simplicity of functioning do not go together. Steve told the designers at the conference, "The main thing in our design is that we have to make things intuitively obvious."

He applied the principle for the Macuser interface. He made the desktop concept literally come alive for the Mac user interface. He said, "People know how to deal with a desktop intuitively. If you walk into an office, there are papers on the desk. The one on the top is the most important. People know how to switch priority. Part of the reason we model our computers on metaphors like the desktop is that we can leverage this experience people already have."

Silicon Valley didn't care much about industrial designs. Steve wanted to change that. "His design sensibility is sleek but not slick, and it's playful. He embraced minimalism, which came from his Zen devotion to simplicity, but he avoided allowing that to make his products cold. They stayed fun," said Maya Lin, the designer of Washington's Vietnam Veterans Memorial, who met Steve at the design conference.

Steve gave credit for his design taste to Japanese Zen Buddhism. He found it to be aesthetically sublime. He loved Kyoto gardens. He said, "I am deeply moved by what culture has produced, and it's directly from Zen Buddhism."

He told Bill Atkinson, "Great art stretches the taste, it doesn't follow tastes." He loved Mercedes design and wanted to do the same with the Macintosh. He wanted the Mac to be as simple and user friendly like most of the appliances used at homes. He spent time studying 
appliances at Macy's at one weekend. He gave suggestions to the Mac team on lines, curves and bevels for the design of the Mac. One of the members said, "Even though Steve didn't draw any of the lines, his ideas and inspiration made the design what it is. To be honest, we didn't know what it meant for a computer to be "friendly' until Steve told us."

Bill Gates and Microsoft are often accused of copying Mac graphical user interface. Microsoft was going to create graphical software for the Macintosh. The Mac team showed Gates smooth curser movement across the screen. But one of the team members later said, "It made clear to me that Gates was not the kind of person that would understand or appreciate the elegance of a Macintosh."

Steve wanted the Mac and its software so easy to use that it didn't require manuals for users to go through to know it's working. Gates thought it was a dumb idea. He in fact had people who were working on manuals. Mac team and Microsoft team started working together. When Microsoft members started asking detailed questions about the Macintosh operating system, Mac team started suspecting about the possibility of Microsoft copying Mac's graphical user interface. Andy Hertzfeld had warned Steve about it. Fears of Mac team came true in 1983 when Microsoft made announcement of developing new operating system for IBM PCs which too would have a graphical user interface. They called it "Windows".

Steve was furious to hear it. Gates calmly replied to Steve, "I think it's more like we both had this rich neighbor named Xerox and broke into his house to steal the TV set and found out that you had already stolen it." Gates later gave a demo to Steve which Steve found as "a piece of shit". That cooled off things for a while between the two. When Microsoft released Windows 1.0 it indeed lacked the kind of elegance that Mac interface had. However, one thing eventually made Microsoft successful was that kept working on the product to make it better. Unlike Apple, Microsoft never got things right in the first shot.

Talking to Fortune later in 1998, Steve said, "Innovation has nothing do with how many R\&D dollars you have in your budget. When Apple came up with the Mac, IBM was spending at least 100 times more on R\&D. It's about people you have, how you're led, and how much you get."

Mac also became the first computer to introduce itself. A speech generator turned text into spoken words when Steve gave demo. He said, "But today, for the first time ever, I'd like to let Macintosh speak itself." Mac started speaking, "Hello, I'm Macintosh. It sure is great to get out of that bag. Obviously, I can talk. But right now, I'd like to sit back and listen. So, it is with considerable pride that I introduce a man who's been like a father to me, Steve Jobs." Steve was criticized for being rough with people. He himself accepted that sometimes he was difficult to get along with. But the fact was no one at Apple had the innovative mind like that of Steve to create an amazing product like that of Macintosh. It was beyond any committee or focus group's imagination.

Creation of Mac, almost made a virtual company inside Apple. Steve called the team 'intrapreneurial' which he didn't want lose entrepreneurial focus by getting involved in rest of matters at Apple. In 1984 talking to Newsweek he explained the concept of 'intrapreneurs', "a group of people going, in essence, back to the garage, but in a large company." (Steve started Apple in his father's garage.)

The euphoria that got created at the Mac launch soon died down and sales showed no signs of improvement. Its basic flaw was, it was frustratingly slow and underpower computer. Although a text-based display required less than a byte of code, a letter in an elegant font consumed twenty or thirty times more memory. Another problem was that it didn't have internal hard disk drive. Steve called Joanna Hoffman a 'Xerox bigot' when she pointed to the need of such storage device. One Apple insider called it as running a Honda on a one-gallon gas tank. Steve wanted just one floppy disk drive for the Mac. Another problem with Mac was, it didn't 
have a fan. A fan meant noise and it didn't fit into Steve's idea of calm computer. The heat made many components to fail. Mac was teased as "the beige toaster".

One Apple executive, Betsy Pace was working on Mac for preparing her speech which she was going to give in front of several hundred Apple employees. She was using first generation Mac. With no disk drive and short internal memory, the data was getting stored onto a floppy disk. The computer needed instructions from the software disk after every couple of paragraphs. The disk kept popping out of the drive, with the screen calling for the disk to be reinserted. (Mac team members called it "Disk Drive Olympics".) After every few minutes, the scene kept repeating, breaking her chain of thoughts. Steve wanted to keep the costs down to make it affordable to a common man. The price tag that Steve had decided didn't include the cost of a hard drive. It turned out to be a huge and costly mistake for Apple. One of the management philosophies of Steve was that it was important 'to bet the company' on some new idea or technology. Mac was such a product for him which he thought would not only take Apple to new heights but was also would change the entire personal computer industry. Macintosh couldn't do wonders on the sales front but it did change the whole personal computer industry.

Windows 95 was released in the year 1995 and went on to become the most successful operating system over. Steve always accused Microsoft of copying Mac graphical user interface. In one of the interviews after his ouster from Apple, Steve said, "Microsoft simply ripped off what other people did. Apple deserved it. After I left, it didn't invent anything new. The Mac hardly improved. It was a sitting duck for Microsoft."

In order to make out of the world user interface, unfortunately one of the major aspect of storage was overlooked. Steve once said, "You can't talk about profit; you have to talk about emotional experiences" and that remained Apple's attitude: Focus on making the products successful, and financial success will follow.

\section{NEXT/PIXAR}

In 1983, when Steve at Apple, Steve had visited the computer science department at Brown to present the Mac, he was told that university labs required for more powerful machine. He was a head of Macintosh division; Steve even launched a project to make such machine which was called 'Big Mac". But in the meantime, he was ousted from Apple and his successor at Mac division, Jean-Louis Gassee, cancelled the project.

In August 1985, he met Stanford Biochemist Paul Berg. Berg talked about how it was difficult to do experiments in a biology lab. Steve gave suggestion of making simulations on computer. Berg told him that computers with such capacities were extremely expensive for the university lab. That made Steve think about new business possibility for his second company NeXT. Berg remembered, "He had it in his mind to start a new company. He was young and rich, and had to find something to do with the rest of his life."

In the same year Steve declared about the shipment of NeXT computer within just one and half year. One of the engineers had suggested him to do it 1988. He replied, "If we do that, the world isn't standing still, the technology window passes us by, and all the work we've to throw down the toilet."

However, Steve could manage to launch NeXT computer only in 1988. Indeed, it had lot of innovative features like a dictionary, a thesaurus, and the Oxford Dictionary of Quotations. It turned out to be one of the pioneers of the concept of searchable electronic books. At the demo he also showed how computer could play speeches, send emails with audio attachments and record voice. With his excellent marketing abilities, he made launched the NeXT computer in a showman style. But soon the hype couldn't help in its sales. Fully automated NeXT factory had capacity of making ten thousand units per month. But in 1989 sales were meagre of just four hundred a month. 
However just like Mac changed the face of personal computer industry, NeXT too had a chance of changing power balance in computer industry. NeXT got into alliance with IBM for licensing out its software. He flew to New York and to show the system at IBM headquarters. IBM engineers were particularly got impressed with object-oriented system. The general manager of workstation at IBM got so impressed by Steve that he named his newborn son Steve. However, licensing operating system wasn't part of Steve's nature. The alliance didn't last long.

However NeXT computer has one huge thing to its credit. Tim Berners-Lee invented the World Wide Web using NeXT machine. He was working at CERN, the European Particle Physics Laboratory in Geneva, Switzerland. He could do it because NeXT machine came up a ready-to-use e-mail account. Steve had pitched the machine as not only for personal computing, but about "interpersonal computing". Berners-Lee credited NeXT software which made his programming work "remarkably easy." In October 1990, he started the work, completed it in December, and made it available to the world in the summer of 1991. He kept redefining it for the next couple of years. The Web got forty million users within about five years.

Berners-Lee wanted to show this code to Steve at a NeXT developers' conference in Paris. It was a large and popular conference and Berners-Lee was at the end of the line. Steve was seeing the work of each developer. Just before he reached Berners-Lee and the World Wide Web at the end of the row, Steve's aid signaled him that they should go or would miss the flight back to America. So, Steve turned away and didn't get see the program that Berners-Lee had written that changed the world later.

\section{PIXAR}

Ed Catmull headed the computer division of George Lucas's film studio. The division made hardware and software which produced digital images. It also had a computer animator which made animation shorts. John Lasseter headed the group.Lucas was going through an acrimonious divorce and he wanted to sell the division to get money. In the summer of 1985 just before he was ousted from Apple, Steve had visited the division and was so impressed with the work that he insisted John Sculley, Apple CEO to buy the division for Apple. He loved computer graphics.

When Steve met Lucas, he told Steve that the people in the division were more interested in making animated movies than making computers. "You know, these guys are hell-benton animation," Lucas told him. Finally the deal was reached in January 1986 with Steve investing $\$ 10$ million and got $70 \%$ stake. Rest $30 \%$ of the stock was distributed to founding employees, right down to the receptionist. Steve recalled, "I realized they were way ahead of others in combining art and technology, which is what I've always been interested in."

The company took its name from the name of computer which it produced, Pixar Image Computer. Steve was mostly busy with NeXT and he occasionally kept visiting Pixar. Although little but his presence was inspiring. Alvy Ray Smith, another founder of the computer division recalled, "Steve's got it: the power of the tongue and the web of words that catches people up. We were aware of this when we had board meetings, so we developed signals - nose scratching or ear tugs - for someone had been caught up in Steve's distortion field and he needed to be tugged back to reality."

The Pixar Image Computer was sold at \$125,000. It was intended for animators and graphic designers for it. But also made market for itself in medical industry with rendering CAT scan data in three-dimensional graphics. It also created market for itself in the intelligence field where it sent information from reconnaissance flights and satellites. But Steve was seeing beyond specialized markets. He made Pixar come up a lower cost version of the computer at $\$ 30,000$ so that it could be sold to people at large. He opened sales offices in major cities. His assumption was that creative people would figure out new ways of using the machine. 
Pixar got into agreement with Disney for computer animations. Disney thus became the largest customer of Pixar. During Pixar's financial troubles, it gave Pixar a sigh of relief. But Steve was seeing beyond just licensing computer production system. He told Jeffrey Katzenberg, the head of Disney's film division that Pixar would like to make a movie with Disney. Disney's financial might would have made it possible. Katzenberg agreed to it and after months of negotiations the deal was finally sealed in May 1991. The deal gave right to Disney to own the picture and the characters in it, along with control over creation. Pixar got $12.5 \%$ of ticket revenues that would come from the movie. The deal also gave a choice to Disney to make or not make next two movies with Pixar and right to make sequel with or without Pixar. Disney could have opted out of the movie anytime with only small penalty. Pixar animation head, John Lasseter was the brain behind the movie which was called "Toy Story".

Steve wasn't involved much into the creative process. Keeping tight control over every aspect of product was part of his nature. He was especially particular about designs. But he respected and trusted Lasseter and other artists at Pixar. So he was mostly involved in managing relations with Disney.He also focused on keeping costs under control. Katzenberg felt impressed with it. At turbulent times with Disney, his tough negotiations skills kept the project sailing. Seeing artistic and technical superiorities of the movie, Steve could sense that the movie might transform the movie industry.

Toy Story got phenomenal box office success. It grossed \$362 million worldwide making it the biggest hit of the year. It was also critically acclaimed. All the seventy-three critics gave it a positive review on Rotten Tomatoes. But most of the reviews called it a Disney movie. That made Steve aggressively emphasize that it was after all a Pixar creation and Disney was just a distributor of the movie. He pointed that after the success of 'Snow White' every major studio was trying to get into animation business. Prior to Toy Story, only Disney could produce feature animated film that got box office success. He called Pixar as the second studio to do so.

Steve knew Pixar needed money so that it could put half of the finances for producing movie and renegotiate its deal with Disney. Steve decided to take Pixar public after one week of Pixar release. Most of the investment bankers were doubtful about its success. Even Lasseter was nervous and suggested Steve to wait till their second movie. But Steve stayed firm on his decision. Indeed, Pixar IPO turned out to be successful beyond even wildest imagination making Steve rich by $\$ 1.2$ billion with his $80 \%$ stake. But he maintained that money didn't matter to him much.

By 2010, Pixar had won twenty-two Academy Awards and collected more than $\$ 5.5$ billion worldwide. Out of hundred all-time best American films, Toy Story was ranked ninety-ninth on the American Film Institute's list. Only Disney's Snow White and The Snow White were the other two animated movies which could find place themselves in the list.

After Toy Story success Pixar made its second movie 'A Bug's Life' which was released in 1998.It was based on insects. Another movie Antz which was also about insects had got released. It was made by former head of Disney's motion picture division Jeffrey Katzenberg under his banner of DreamWorks SKG. Steve was furious with Katzenberg the original idea of making movie on insects was that of Pixar's John Lasseter and Katzenberg had copied it. Although Antz got success, A Bug's Life surpassed it grossing more money. But importantly success of 'A Bug's Life' proved that Toy Story was not a fluke and Pixar was not a one-hit wonder. Talking about it what Steve had said, is something that can prove to be a good guide for every businessman. He believed in making something great and then striving to make something better. He said, "There's a classic thing in business, which is the second-product syndrome. I lived through that at Apple. My feeling was, if we got though our second film, we'd make it." 
Like Apple, Pixar too became a valuable brand. He always had a passion of making a lasting company. Hewlett-Packard always remained an example in front his eyes since he worked at the company when he was just twelve. He knew that it was a well-run company that who could innovate far more than a single creative individual. Steve recalled, "I discovered that the best innovation is sometimes the company, the way you organize a company."

\section{REFERENCES}

[1] Jeffrey S. Young, William L. Simon, iCon: Steve Jobs The Greatest Second Act in the History of Business, John Wiley \& Sons

[2] Carmine Gallo, The Innovation Secrets of Steve Jobs, Tata McGraw- Hill

[3] Carmine Gallo, The Presentation Secrets of Steve Jobs, Tata McGraw- Hill

[4] Michael Moritz, Return to the Little Kingdom, Duckworth Overlook

[5] Jay Elliot and William L.Simon, The Steve Jobs Way : Leadership for a New Generation, Jaico Publishing House

[6] Jay Elliot, Leading Apple with Steve Jobs, Times Group Books

[7] Karen Blumenthal, Steve Jobs: The Man who Thought Different, Bloomsbury Publishing

[8] www.allaboutstevejobs.com 